\title{
Multilingualism, Russian language and Education in Kyrgyzstan
}

\section{Mustajoki, Arto}

2008

Mustajoki , A , Orusbaev , A \& Protassova , E 2008 , ' Multilingualism, Russian language and Education in Kyrgyzstan ' , International Journal of Bilingual Education and Bilingualism , vol. 11 , no. 3\&4(2008), pp. 476-500 .

http://hdl.handle.net/10138/154487

acceptedVersion

Downloaded from Helda, University of Helsinki institutional repository.

This is an electronic reprint of the original article.

This reprint may differ from the original in pagination and typographic detail.

Please cite the original version. 
This article was downloaded by: [University of Helsinki]

On: 06 May 2015, At: 00:43

Publisher: Routledge

Informa Ltd Registered in England and Wales Registered Number: 1072954 Registered office:

Mortimer House, 37-41 Mortimer Street, London W1T 3J H, UK

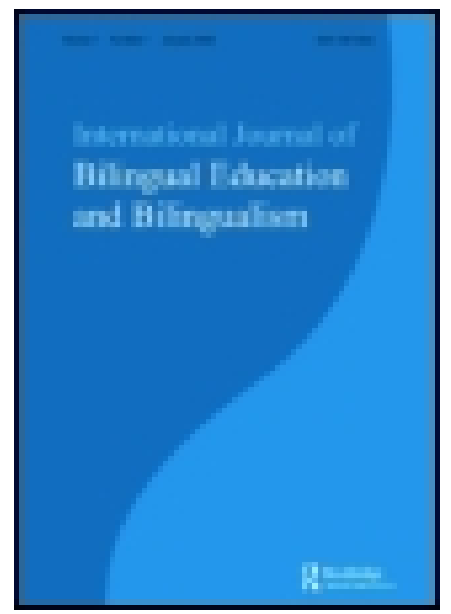

\title{
International J ournal of Bilingual Education and Bilingualism
}

Publication details, including instructions for authors and subscription information:

http:// www.tandfonline.com/loi/ rbeb20

\section{Multilingualism, Russian Language and Education in Kyrgyzstan}

\author{
Abdykadyr Orusbaev ${ }^{a}$, Arto Mustaj oki ${ }^{b} \&$ Ekaterina Protassova ${ }^{b}$ \\ ${ }^{a}$ Kyrgyz-Russian Slavic University, Kyrgyzstan \\ ${ }^{\mathrm{b}}$ University of Helsinki, Finland \\ Published online: 19 Dec 2008.
}

To cite this article: Abdykadyr Orusbaev , Arto Mustajoki \& Ekaterina Protassova (2008) Multilingualism, Russian Language and Education in Kyrgyzstan, International J ournal of Bilingual Education and Bilingualism, 11:3-4, 476-500

To link to this article: http:// dx. doi. org/ 10.1080/ 13670050802148806

\section{PLEASE SCROLL DOWN FOR ARTICLE}

Taylor \& Francis makes every effort to ensure the accuracy of all the information (the "Content") contained in the publications on our platform. However, Taylor \& Francis, our agents, and our licensors make no representations or warranties whatsoever as to the accuracy, completeness, or suitability for any purpose of the Content. Any opinions and views expressed in this publication are the opinions and views of the authors, and are not the views of or endorsed by Taylor \& Francis. The accuracy of the Content should not be relied upon and should be independently verified with primary sources of information. Taylor and Francis shall not be liable for any losses, actions, claims, proceedings, demands, costs, expenses, damages, and other liabilities whatsoever or howsoever caused arising directly or indirectly in connection with, in relation to or arising out of the use of the Content.

This article may be used for research, teaching, and private study purposes. Any substantial or systematic reproduction, redistribution, reselling, loan, sub-licensing, systematic supply, or distribution in any form to anyone is expressly forbidden. Terms \& Conditions of access and use can be found at http://www.tandfonline.com/page/terms-and-conditions 


\title{
Multilingualism, Russian Language and Education in Kyrgyzstan
}

\author{
Abdykadyr Orusbaev \\ Kyrgyz-Russian Slavic University, Kyrgyzstan
}

\section{Arto Mustajoki and Ekaterina Protassova University of Helsinki, Finland}

The study provides an overview of the sociolinguistic situation in Kyrgyzstan and the current role of Russian and Kyrgyz in the republic. We present initial results of a mass survey of language use that show that the efforts to introduce the Kyrgyz language on all levels of societal use had some effect. At the same time, Kyrgyzstan is a multinational multilingual state with a high degree of mixed marriages and ethnic tolerance. To know the national language is prestigious and important, yet many Kyrgyz and representatives of other ethnicities prefer to have their children instructed mainly in Russian because Russian provides access to better education, employment, information, and economic advancement. Among the Kyrgyz, mastery of their own language is widespread, whereas for other peoples of Kyrgyzstan, understanding of the specific characteristics of the national ethnolinguistic identity is in the process of development.

doi: $10.1080 / 13670050802148806$

Keywords: Kyrgyz, Russian, language policy, bilingualism, post-Soviet studies

\section{Introduction}

Kyrgyzstan is a Central Asian republic where the Kyrgyz make up about $65 \%$ of the population. The primary languages used in the region are Kyrgyz, Russian, Uzbek, Tajik, Turkish, and German. Since proclaiming independence, Kyrgyzstan has proceeded to build a new historical identity of Kyrgyzstani. This idea is based upon the seven precepts of the epic national poem 'Manas' (www.welcome.kg/ru/manas): (1) unity and solidarity of the nation; (2) interethnic agreement, friendship, and collaboration; (3) national honor and patriotism; (4) tireless labor towards prosperity and well-being; (5) humanity, magnanimity, and tolerance; (6) harmony with nature; (7) fortification and defense of the Kyrgyz state system. Among the post-Soviet states Kyrgyzstan, closely following Belarus (see Giger \& Sloboda, this issue), does not consider the Russian language to be a threat to its national security or historical identity. Language planning is developing, but it seems that the Kyrgyz language is not yet ready to be an omnipotent means of the national academic, administrative, interethnic and intercultural communication. Russian is commonly studied by members of the younger generation because they want to study at Kyrgyz universities where the main scientific literature and textbooks are still in Russian, conduct business with Russia, or work or live in Russia where the standard of living is higher. The tensions between some ethnic groups also 
promote the use of Russian as a lingua franca. At the same time, proficiency in Russian as a second language is declining in the new generation.

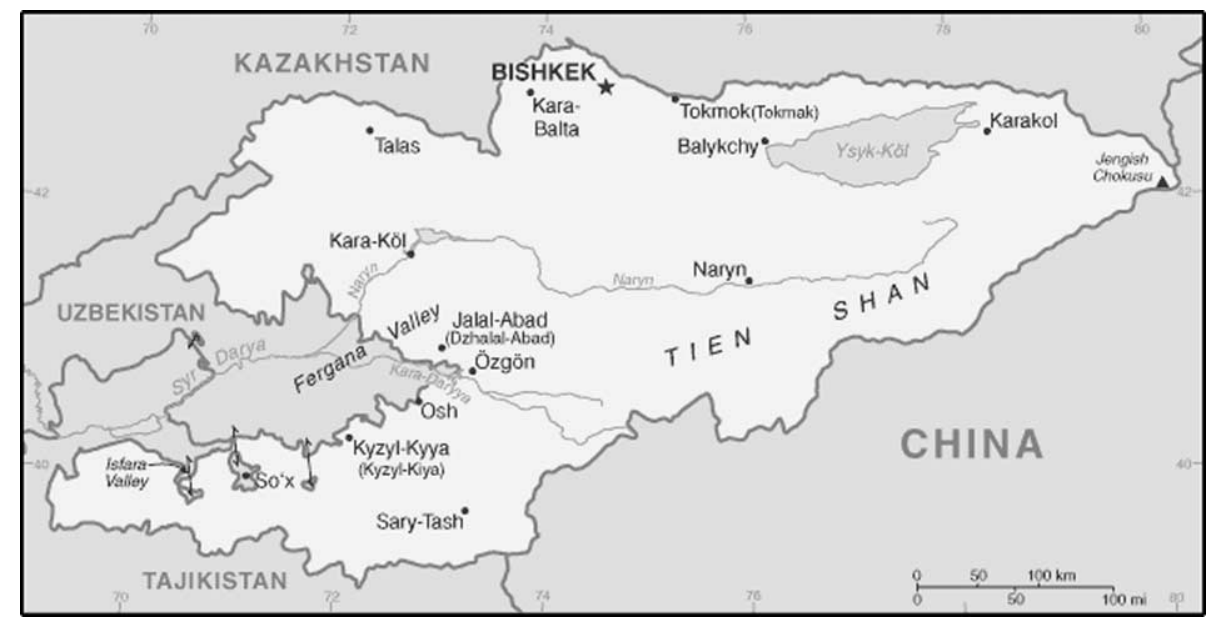

Map Kyrgyzstan (Source: https://www.cia.gov/library/publications/theworld-factbook/geos/kg.html)

The purpose of this paper is to provide an overview of the current situation in Kyrgyzstan, affected by the previous experiences of multilingualism, examples of the neighboring countries, and new nation-building expectations. The focus of our discussion is the changing role of Russian and its use as the language at the service of the growing Asian economies, denationalized and free from the Soviet historical cultural background. The new hybrid culture and partly regionalized Russian language serve to unify Central Asian republics with Russia. The former republics of the Soviet Union still function like communicating vessels: when the economic situation in Russia ameliorates, their attitude towards its policy and its language changes.

In the following, we will first introduce our theoretical framework and previous studies of language policies and practices in Kyrgyzstan. Then, we will discuss the history of language policy and education in Kyrgyzstan, and the current state of affairs. Since the 1991 independence, language policies and practices have changed many times and the latter discussion had to be revised several times even during the process of writing this paper. Next, we will outline the most interesting results of a large survey about the use of languages and linguistic identity in Central Asia, funded by INTAS, the International Association for the promotion of cooperation with scientists from the New Independent States of the former Soviet Union (www.intas.be).

\section{Theoretical Framework}

The focus of this paper is on self-identification in the changing sociopolitical circumstances. We understand self-identification as a complex interactive 
process of categorization, authentication, and demarcation, conducted on psychological and semantic levels under given sociopolitical circumstances. This process takes place in the context of the interplay of inside and outside factors, once or repeatedly at different points in the life span of individuals, and is dependent on the potential implications of sincerity. In their discussion of negotiations of identities in multilingual contexts, Pavlenko and Blackledge (2004) underscore the importance of considering language ideologies and power relations in a given context; they also emphasize issues of social significance and social justice.

Kyrgyzstan, where several sociopolitical waves have superseded each other in the last two decades, offers an excellent site for the study of such negotiations of identity. Research conducted in Kyrgyzstan over the last two decades shows that Kyrgyz and Russian were competing, but not on the common ground, and that ethnic Kyrgyz and ethnic Kyrgyzstan Russians had to position themselves again and again towards the state where they live and lived before, the passport they have and had before, the languages they speak and learn now, the ideologies they share and shared before and the work they can do (Huskey, 1995; Kolpakov, 2001; Korth, 2005; Landau \& KellnerHeinkele, 2001; Tagaev, 2004; Wright, 1999). The dissolution of the Soviet Union and its ideology had to be discussed and experienced not only on the official level, but also at the grass-roots level. First, former citizens of the USSR had to reject their Soviet identities; then, they had to restructure and build up their ethnic identities; afterwards, they had to work on individual, group, and state levels of identification, to rethink historical processes and to find the fulcrum of their balanced personality (Elebayeva et al., 2000; Mullerson, 1993; Smith et al., 1998).

In all post-Soviet countries, language became an important instrument in defining the new independent states and nations; perhaps it was even excessively accentuated in the first years after independence. The consolidation of the nation was conducted based on language, even if the states were multinational. Fierman's (1997) analysis of transformations of identities in Central Asia during the years following the 1991 independence shows that the key sensitive points were the lowering of the status of Russian, the weakening of the bonds within the former USSR, and the need to learn the titular language. It was only later that the states began to address the interests and rights of different ethnic minorities. In Kyrgyzstan, many government initiatives had exceedingly optimistic visions of multilingualism or of the possibilities to organize life in Kyrgyzstan on the one-language basis, without keeping Russian as an official language (Heuer, 2001; Huskey, 1995; Koenig, 2000; Kolpakov, 2001; Mamedov, 2005; Pannier, 1996). This situation can be compared to other Central Asian countries where Islam also plays an important role (Bergne, 2003; Bingol, 2004; Landau \& Kellner-Heinkele, 2001; Olcott, 1997).

Eventually, the new Kyrgyz government faced the need to integrate nonKyrgyz elements into the new conception of the Kyrgyz state (Brubaker, 1994; Commercio, 2004; Laitin, 1996); to balance one's own interests with those of the Russian Federation that remains an important economic partner (Khruslov, 2006; Tishkov, 1997), and to have solid ties to other countries of the world 
while pursuing one's own geopolitical interests (Gleason, 2001; Khazanov, 1995; King \& Melvin, 1999, 2000; Kreindler, 1997; Schlyter, 2001). Schulter (2003) argues that past tensions and suspicions can be overcome through integration, fostered through changes in the school curriculum and the emphasis on multiculturalism and multilingualism among the new 'Kyrgyzstani' generation.

An important factor in these changes of positioning is that of self-esteem, which is built in the process of claiming historical, intellectual and cultural heritage (see, for instance, discussions on the websites www.bpc.kg, www. politika.kg). The meaning and interpretations of the past vary in these discussions. Those who want to turn to a Kyrgyz-dominant or Kyrgyz-only state exalt the history and praise the Kyrgyz people for all their deeds. Those who want to maintain Russian as a communication tool argue for the need to use it as a lingua franca and to continue the common academic space with countries where Russian is still spoken.

Finally, we have to briefly mention our own reliance on the local academic knowledge, traditions, and ideas, which at times diverge from those espoused in the Western literature. Whereas in English-language publications, some researchers (e.g. Wright, 1999) attribute negative developments in Kyrgyzstan to the Slavic influence, academics working locally recognize the complexity and tenacity of regional, clan, and tribal loyalties, pre-modern forms of governance, and personal relationships, which the Soviet rule diminished but did not extinguish (Berdikeeva, 2006; Dukenbaev \& Hansen, 2003). As a result, the government faces a dilemma: they have to create an entirely new national identity based either on the artificially reconstructed imaginary pre-Soviet Kyrgyz nation or on the existing system of local-central relationships and coreperiphery ties.

\section{Demographic and Sociolinguistic Profile of Kyrgyzstan}

Kyrgyzstan is divided administratively into the capital Bishkek with approximately 900,000 inhabitants and seven provinces. There is one exclave Kyrgyz village on the territory of Uzbekistan, as well as four Uzbek and two Tajik enclaves on the territory of Kyrgyzstan. According to the 1999 Census (www.stat.kg), Kyrgyzstan has 4,822,938 inhabitants. It is a country with a growing, albeit sparse population. Almost $65 \%$ of the population refers to themselves as Kyrgyz. The country is also inhabited by more than ninety other ethnicities. The largest ethnic minority are Uzbeks (13.8\%) who mostly live in the South, in the regions of Osh and Jalal-Abad. The next group is Russians $(12.5 \%)$ who mostly live in the North. Other prominent ethnic groups include Dungans, Ukrainians, Uyghurs, Tatars, Kazakhs, Tajiks, Turks, Germans, and Koreans. According to the All-Union Censuses of 1979, and the Kyrgyz Census of 1999 , about $70 \%$ of the country's population declared that they were proficient in Kyrgyz (only 53\% could speak Kyrgyz in 1989). Fluency in Russian was reported by ethnic Russians, 98\% of Ukrainians, $81 \%$ of Kazakhs, one-third of Kyrgyzs and Uzbeks, and the majority of other ethnic groups (www.stat.kg). 
Table 1 Population of Kyrgyzstan (according to the All-Union Censuses of 1979 and 1989, and the Kyrgyz Census of 1999)

\begin{tabular}{||l|r|r|r|r|r|r||}
\hline & \multicolumn{2}{|c|}{1979} & \multicolumn{2}{c|}{1989} & \multicolumn{2}{c|}{1999} \\
\hline & Size (1000s) & \multicolumn{1}{c|}{$\%$} & Size (1000s) & \multicolumn{1}{c|}{$\%$} & Size (1000s) & \% \\
\hline The whole population & $3,522,832$ & 100.0 & $4,257,755$ & 100.0 & $4,822,938$ & 100.0 \\
\hline Kyrgyz & $1,687,382$ & 47.9 & $2,229,663$ & 52.4 & $3,128,147$ & 64.9 \\
\hline Uzbeks & 426,194 & 12.1 & 550,096 & 12.9 & 664,950 & 13.8 \\
\hline Russians & 911,703 & 25.9 & 916,558 & 21.5 & 603,201 & 12.5 \\
\hline Dungans & 26,661 & 0.8 & 36,928 & 0.9 & 51,766 & 1.1 \\
\hline Ukrainians & 109,324 & 3.1 & 108,027 & 2.5 & 50,442 & 1.0 \\
\hline Uyghurs & 29,817 & 0.8 & 36,779 & 0.9 & 46,944 & 1.0 \\
\hline Tatars & 71,744 & 2.0 & 70,068 & 1.6 & 45,438 & 0.9 \\
\hline Kazakhs & 27,442 & 0.8 & 37,318 & 0.9 & 42,657 & 0.9 \\
\hline Tajiks & 23,209 & 0.7 & 33,518 & 0.8 & 42,636 & 0.9 \\
\hline Turks & 5,160 & 0.1 & 21,294 & 0.5 & 33,327 & 0.7 \\
\hline Germans & 101,057 & 2.9 & 101,309 & 2.4 & 21,471 & 0.4 \\
\hline Koreans & 14,481 & 0.4 & 18,355 & 0.4 & 19,784 & 0.4 \\
\hline Other ethnicities & 88,658 & 2.5 & 97,842 & 2.3 & 72,175 & 1.5 \\
\hline \hline
\end{tabular}

Source: www.stat.kg

As seen in Table 1, in the years since the 1991 independence, the share of Russians, Ukrainians, Germans, and Tatars in the country's population has significantly diminished, mainly as a result of emigration. On the other hand, the numbers and proportions of the ethnic Kyrgyz and Uzbeks have increased. Scholars discuss different reasons for the exodus of Russian-speakers from Kyrgyzstan. Some describe these emigrants as victims of the conflict between Russians and other European ethnics on the one side and indigenous peoples on the other side. This conflict is leftover from the Soviet times, when the urban, mostly Russian-speaking (even if not Russian) population boasted of its progressive views and disdained the values, traditions, and attitudes of the title nation, while protectionism did not allow Russians to occupy certain posts in the local hierarchy (Savoskul, 2001). Kosmarskaya (2006) questions this oversimplified portrayal. Based on in-depth interviews, collected during numerous field trips to the region, she argues that 'what looks on the surface like "ethnic" confrontation is to a large extent a conflict of social (ethno-social) groups engendered by a radical redistribution of power and the restructuring of the Soviet sociopolitical hierarchy' (Kosmarskaya, 2006: 594). Redefining the status of the Russian-speaking communities, Kosmarskaya notes that they display a wide range of characteristics of their way of life, consciousness, and 
behavior. The community of 'Russians of Kyrgyzstan' or 'Central Asian Russians', dormant until the collapse of the USSR, is specifically based on a sharp differentiation from Russians who have not lived for generations among other peoples under differing climatic and cultural circumstances. After the independence, large numbers of these Russians and russophones repatriated to Russia. Some however were unable to assimilate and returned to Kyrgyzstan. Kyrgyzstan has a relatively mild regime with a weak control over social life, and the true opposition tends to be not 'Russian-speakers against titulars', but rather 'powers against a wide opposition', commonly ordinary people (Kosmarskaya, 2006).

Despite ongoing political, regional, ethnic, and religious rivalries, many experts state that the country has some of the most dynamic social movements in Central Asia because the activists distrust many governmental institutions and support societal reforms (Kuchukeeva \& O'Loughlin, 2003). Western influence can be seen in financial structures and the transition to market economy, yet agriculture and trade remain to a large degree traditional, which is understandable given that about two-thirds of the population lives in rural areas. At present, rural life is dominated by local languages. Islam is gaining strength (75\% of the country's population are Muslim, mostly Sunni), though the state is a secular one. In the South, there is a tendency toward introducing the Shariat rules in everyday life (e.g. Rotar, 2006). Some shamanist beliefs and worship of animals, connected to pastoral nomadic culture, have survived. Global events, the happenings in the Islamic world, and the situation in Russia provoke the back-and-forth migration of different groups and are affecting the well-being of the Kyrgyzstani more than ever.

At present, there are also several international organizations working in Kyrgyzstan with different goals. The Organization for Security and Cooperation in Europe (OSCE) Center in Bishkek is building a relationship of trust and confidence with the country's ethnic communities. It strives to intensify recruitment activities within minority communities in order to address the falling minority representation in the country's police service, offers training in the management of the sensitive interethnic relations, and implements the 'Integration through Education' program, supporting multicultural, bilingual and multilingual education (www.osce.org/bishkek). UNESCO's international social science program Management of Social Transformations (MOST) has established a joint project with colleagues from Switzerland to introduce policy-makers, legislators, judiciary officials, and representatives of public and non-governmental organizations from Kyrgyzstan to the functioning of democratic governance under the conditions of ethnic, linguistic and cultural diversity (www.unesco.org/most/kyrgyz.htm).

\section{Languages of Kyrgyzstan}

Surrounded by Kazakhstan in the north, Uzbekistan in the west, Tajikistan in the southwest and the People's Republic of China in the southeast, Kyrgyzstan is one of the Central Asian countries. The Tian Shan Mountains, the Fergana Valley and the Lake Issyk-Kul are geographic symbols of the land and important pieces of the national identity. 
Kyrgyz is a Turkic language understood by people who speak other Turkic languages and is closely related to Kazakh, so that speakers of these languages can understand each other without having studied each other's languages; however, Mongolian and Altaic elements are greater in Kyrgyz than in Kazakh (Abduldaev, 1998; Oruzbaeva, 1997; Sartbaev, 1986). Kyrgyz emerged as a distinct language of a separate ethnic group in the fifteenth century, and has been studied since the late nineteenth century. The first manual of Kyrgyz was published in 1922, and since 1924, grammars of Kyrgyz began appearing (Abdymambetova, 2001; Fedchina, 1967; Kirgizskaja SSR, 1982). The epic poem 'Manas' is a well-known source for the study of the history of the Kyrgyz language and culture (it can be read in Russian on the website www.welcome.kg/ru/manas).

As to alphabet, the Kyrgyz have used adapted versions of Arabic (sporadically until 1923, later officially), Latin (1928-1940) and Cyrillic script (since 1940). All in all, during the Soviet times, the unified literacy, both for the written and oral forms of the language, was elaborated, codified, normalized and spread among the population; Kyrgyz literature, art, and history were popularized. At present, some voices suggest the transition to the Latin script - this reflects attempts to unify all Turkic-speaking countries around Turkey.

In the course of their history, the Kyrgyz were influenced not only by different Turkic neighbors, but also by Mongols, Kalmyks, Afghani, Pamirs, Uyghurs, Chinese, and Russians. In 1876, the territory became a part of the Russian Empire; in 1919, a part of the Soviet Union; and in 1936, a Soviet Republic (www.kyrgyz.ru). Despite these changes, many Kyrgyz remained nomads and herders and traveled independently of the borders. In the Russian Empire and in the first years after the October revolution, both Kazakhs and Kyrgyz were called Kyrgyz, with the present-day Kyrgyz subdenominated on occasion as 'Kara-Kyrgyz' (kara meaning 'black') (see www.infoplease.com/ country/profiles/kyrgyzstan.html; see also Fedchina, 1967; Hirsch, 2005; Smagulova, this issue). This joint past leads to many local jokes, for example: Kazakhs who feel richer and more civilized and therefore dominant in the area, ask the Kyrgyz to get together again in the joint state; the Kyrgyz respond that they are ready, but only under the name they had together before mid1920s.

\section{History of Language and Education Policies in Kyrgyzstan}

The teaching of the Russian language in Kyrgyzstan began in the nineteenth century, under the Russian Empire, with the goals to have interpreters, translators, representatives, and administrators among the local people; later, democratic, civilization and educational aims played an important role as well (Arzygulova, 2007; Marchenko, 2007).

During the Soviet era, education in the mother tongue, Kyrgyz, became possible from early childhood until postgraduate studies and the ethnographic culture blossomed, while nationalism was suppressed. Non-natives were required to study the Kyrgyz language at school, but this was rarely carried out properly, if at all. As a result, most residents of European origin had a very low level of mastery of the Kyrgyz language. The countryside was dominated 
by Kyrgyz, perceived as 'rural', while the cities used Russian, perceived as 'urban' and preferred by the ethnic Kyrgyz themselves. Since there was relatively little published in and translated into Kyrgyz in comparison with Russian, Russian was the language of access to world literature and culture, especially for those living in the cities. Russian was also taught at all of the so called 'national' schools as the language of interethnic communication of the common state, USSR, so that citizens would have no problems in self-actualization on the all-Union level. Official documents were written in Russian, and when the rural Kyrgyz wrote in Kyrgyz, these letters and documents were translated into Russian in regional centers.

In the late 1960s, the benefits of being educated in Russian (more and better possibilities to study at Russian universities, to be involved in the cultural and economic exchange and to act at the all-Union level) were so evident that russification became widespread, entailing a shift to the Russian language in many administrative domains. For example, writers who addressed their readers in Russian got bigger editions and larger audiences. Though proficiency in the oral Kyrgyz was still common, the Kyrgyz elites preferred to educate their children in Russian schools, with the goal of becoming bilingual with dominant literacy in Russian. The prestigious way of life was connected with the everyday use of Russian as supra-ethnic means of communication among different peoples living in the Soviet Union.

In comparison with the neighboring Afghanistan, which was very much like Kyrgyzstan before the Soviet time, the Kyrgyz educational system may be considered a major achievement of the Soviet regime. Before the October Revolution, only about $1 \%$ of the whole population could read, while by the end of the Soviet Union, about $85-90 \%$ of the whole population was literate either in Kyrgyz or Russian, or both.

\section{Current Language Policies and Practices Language Policies}

The 1989 Law on the State Language celebrated the historical value of the Kyrgyz language, condemned its diminishing use, offered special measures for its protection, and guaranteed the free development of all national languages. After the 1991 independence, the pressure for Kyrgyzification intensified and many Russian-speaking people (locally called 'Europeans' independently of their ethnic origin) chose to leave the country (around 600,000 persons). Some returned because they failed to adjust in Russia.

Starting in 1991, the first president of the independent Kyrgyzstan Askar Akayev ushered in comprehensive economic, political, and educational reforms. Akayev emphasized the secular character of the Kyrgyz state and condemned manifestations of Islamic fundamentalism (these pan-Islamic trends are often linked to more intensive use of Arabic and Turkic languages). The national language Kyrgyz was considered a symbol of state sovereignty and nation building, while Russian was given the status of the language of interethnic communication. The policy of 'Kyrgyzstan is our common home' promoted the support of minorities. Kyrgyzstan became a full member of the 
United Nations, the World Trade Organization, and the International Monetary Fund.

The Law, adopted in 1992, and the Constitution, adopted in 1993, proclaimed Kyrgyz as the only public language from 1997 on (www.krugosvet. $\mathrm{ru} /$ articles/117/1011733/1011733a1.htm). However in 1996, the Russian language gained official status alongside Kyrgyz. At present, the status of Russian in Kyrgyzstan is secured through the 2000 Law on the official language of the Kyrgyz Republic. This law designates Russian as a tool of interethnic communication and the language of access to Russian and CIS education, culture, information, and technologies (Orusbaev, 2003c: 154-155).

On 20 September, 2000, the Kyrgyz president signed a Program for the development of the state language of the Kyrgyz Republic for the years 2000-2010. This program is designed to revitalize, standardize and modernize the Kyrgyz language (first and foremost, in vocabulary) with the goal of introducing it as the language of administration by 2008. The Program regulates the use of Kyrgyz in state administration and business, in education, science, and culture, in official correspondence, etc. An Institute for the state language and culture was created, at the Faculty of Arts of the Arabaev Pedagogical University. A National Commission on the State Language under the auspices of the President was also created, comprising state administrators, scientists, artists, members of civic organizations and cultural activists. It is argued that the Kyrgyz language should be studied, taught, and learned on a large scale, especially by children and the younger generation. Its corpus planning - first of all, creation of terminology - should be worked out and spread. According to the program, from 2007 onwards, an examination in the state language was supposed to become obligatory for those wishing to occupy an official post, but there are doubts that the majority of the current post-holders would pass it (furthermore, at the time this article went into production this examination has not been implemented yet).

The latest 2004 Law on the State Language of the Kyrgyz Republic also aims at the development of the Kyrgyz language and strengthening of its social role. At the same time, a document was published concerning the development of bilingualism on the level of governmental policy and the measures for effective functioning of both languages.

After the so-called Tulip Revolution, Akayev was forced to resign and the new president Kurmanbek Bakiyev was elected in 2005 (for more details, see Marat, 2006a). The new (2006) Constitution has confirmed the status of Russian as an official language, but this Constitution was rejected by the Constitutional jury of the country. The official website of the Kyrgyz Republic, maintained in Russian, reflects these recent events in the republic (www.gov.kg).

\section{Language Practices}

At present, the state language of Kyrgyzstan is Kyrgyz with its national symbolic and cultural function, while Russian, divorced from its links to particular ethnicity, functions as an official language. Yet, discussions about the future of bilingualism and the Russian language in Kyrgyzstan are usually 
heated, and the lack of knowledge of Kyrgyz by some ethnic Kyrgyz is also a major point of contention. The periodic issues of 'Russian Language in Kyrgyzstan' contain numerous debates about the delimitation of functions for both state and official languages in Kyrgyzstan (Krasnov, 1998, 2000, 2002; Orusbaev, 2003b). The feeling of being bearers of an endangered language compels native speakers of Kyrgyz to fight for its rights. They argue that Kyrgyz is a means of ethnic solidarity and unity and a people's common national property, reflecting the degree of cultural development, and that it should completely satisfy people's communicative needs, resolving (self-) contradictions and aiding sovereignty.

Members of the two largest ethnic and linguistic minorities, Russian and Uzbek, also have concerns. They are currently underrepresented in administrative, judiciary, and government structures. In some territorial units, Kyrgyzspeakers dominate but in urban regions and in some valleys they are in a minority, even among the ethnic Kyrgyz. The Uzbek minority is seeking recognition for their language as an official language of Kyrgyzstan, and is calling for proportional representation in administration, which has led to certain ethnic tensions. In particular, Uzbeks claim that there are not enough training opportunities and educational materials in their language. Ethnic Russians also express their dissatisfaction with disproportional representation in the power structures through migration. They not only rely on the Russian authorities, but also self-organize in the name of the struggle for their rights and their group identity.

It is not surprising then that multilingual practices dominate the country's linguistic landscapes. Official signage contains parallel texts in Kyrgyz and Russian, and at times English (Picture 1). The language of advertising also uses

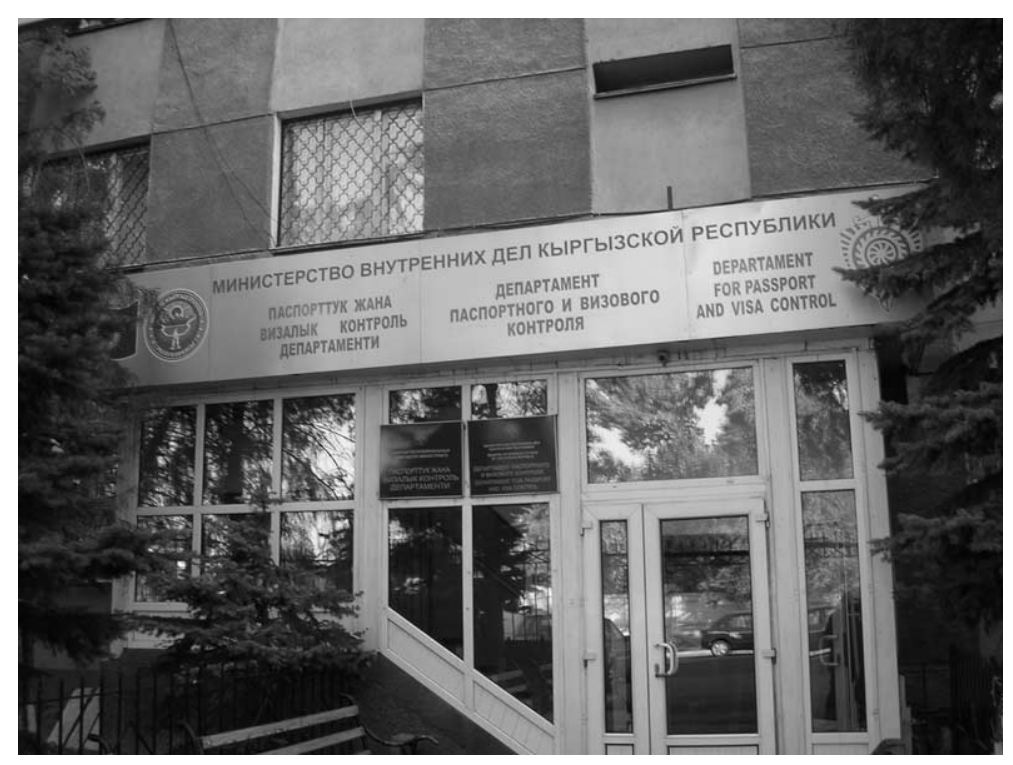

Picture 1 


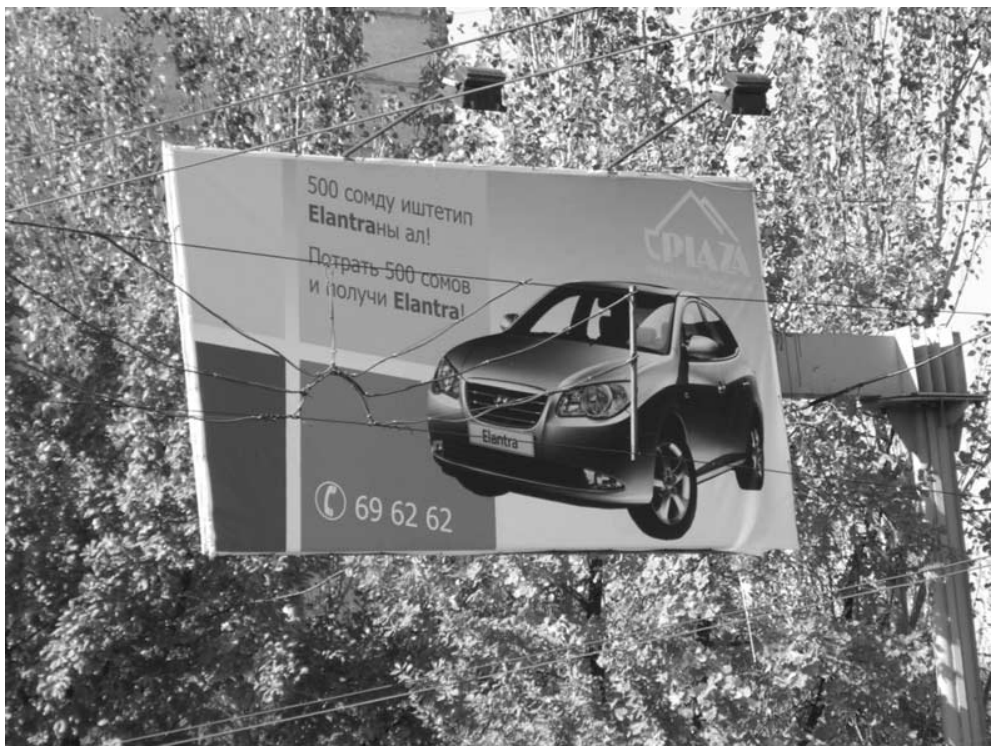

Picture 2

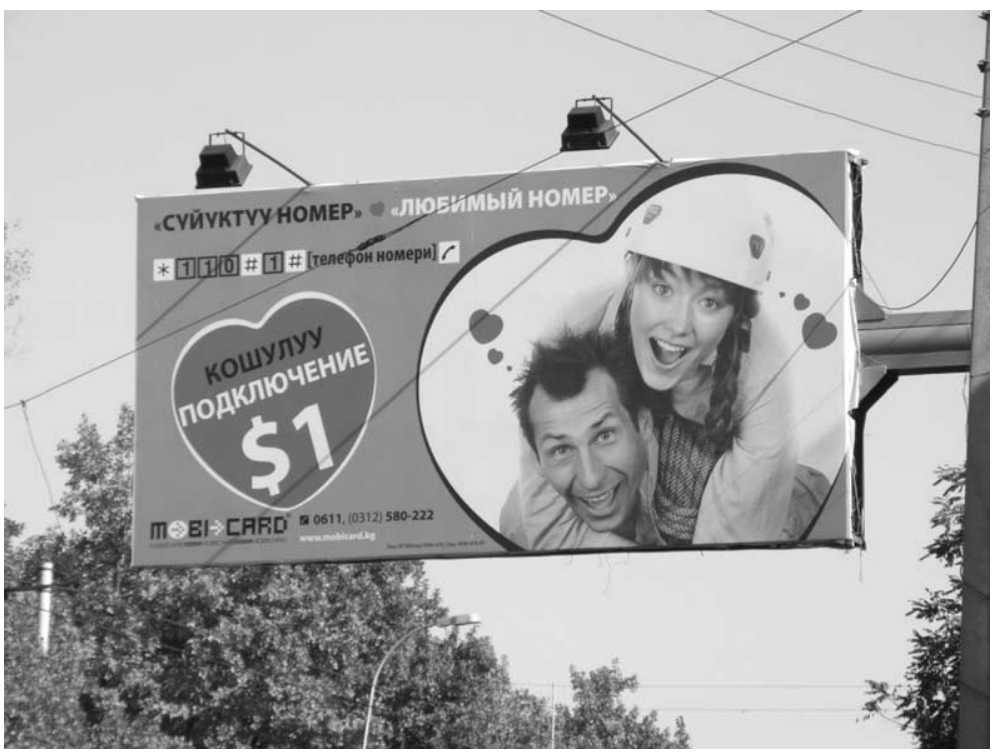

Picture 3

these three languages (Pictures 2 and 3), but the texts may be mixed, rather than parallel, they may also contain neologisms, calques, hybrids etc. (Derbisheva, 2007; Duishekeeva, 2007; Rudov, 2007a,b). Internet resources are much richer and more diversified in Russian than in Kyrgyz, this is a sphere where Russian still dominates. Only a few mass-media outlets use Kyrgyz as their main language, while the vast majority are published and 
broadcast in Russian, and are therefore in the orbit of Russian political and cultural influence (e.g. news can be read at www.pr.kg, www.24.kg or, in English, www.eurasianet.org/resource/kyrgyzstan). Affected through the images translated by the mass media, most Kyrgyz approve of good relations with Russia. Overall, about $70 \%$ of the electronic and paper-printed sources of information are in Russian, mostly from Russia with added materials concerning Kyrgyzstan. Some Russian-language publications, such as Slovo Kyrgyzstana (Kyrgyz Word) or Vechernij Bishkek (Bishkek Evening [News]), are local. Some local broadcasting and media are in local languages. As far as literature is concerned, today, about $92 \%$ of the books in the National library are in Russian, $6 \%$ in Kygyz, and 2\% in other languages, but only a few new publications in Russian arrive on a regular basis. Rural libraries are in decline.

Institutional communication in Kyrgyzstan is commonly multilingual. An analysis of such communication comes from a study by Maksimenko (1999) who examined interactions in three Bishkek enterprises: one state-owned Kyrgyz, and two joint ventures, a Kyrgyz-Russian and a Kyrgyz-Turkish firm. The investigation was focused on educated administrative personnel aged between 20 and 50; these participants represented 10 ethnicities and knew, collectively, 15 languages. The researcher found that about $60 \%$ of the respondents spoke Russian as their mother tongue. Representatives of ethnic minorities (e.g. Uyghur) were able to speak several Asiatic languages, while ethnic Russians preferred to acquire Western European tongues. Minority languages, like Dungan, Uzbek, or Kazakh, were used for communicating with friends and family. Foreign languages (English, German, French) were used for reading, Internet searches, listening to the radio, and watching movies and TV shows. In the Kyrgyz-Turkish firm, Turkish and English were also employed for professional communication and documentation; the two other companies favored Russian for the same purposes. Another sociolinguistic investigation (Grigorieva \& Parmanasova, 2007b: 56-59) of language use in state institutions surveyed 364 respondents, 85\% of whom were Kyrgyz, 8\% Russians, 2\% Kazakhs; among the remaining 5\% were ethnic Uzbeks, Azeri, Ukrainians, Dungans, and Bashkirs. When asked about language use in communication with clients, $44 \%$ of the respondents preferred Kyrgyz (13\% of these used mostly Kyrgyz) and 37\% preferred Russian (22\% of these used Russian only). Some $8 \%$ reported that they never use Kyrgyz and only less then $2 \%$ reported never using Russian.

Despite official bilingualism, however, the documentation in Kyrgyz is already dominating, and there is a clear tendency to translate official papers into Kyrgyz even when they were first written in Russian (this fact influences the quality of written Kyrgyz, especially if it was studied as a second language by the translator). Many documents written first in Kyrgyz serve as models for other people because being mostly socialized in oral variety of their mother tongue, they cannot produce such official texts themselves (Ashirbaev \& Ahmatov, 2001). Only 16\% of administration workers are fluently bilingual in Kyrgyz and Russian (Andreeva \& Khruslov, 2004: 27). This is why, despite the wishful idea of shifting to Kyrgyz, it cannot yet be introduced as a language of administration and there is no examination in the national Kyrgyz language for representatives of the administration. There is also no examination for 
those who wish to obtain Kyrgyz citizenship, although some steps have been made in this direction, and the first versions are forthcoming.

On the other hand, local scientific - including linguistic - work is mostly produced in Russian, a situation that is distinct from current linguistic research traditions in Ukraine and in the Baltic countries where work on national languages is published in these languages. In fact, most active linguists still have difficulties writing scientific articles in Kyrgyz, only Kyrgyz-specialists use Kyrgyz in academic research and publications. Even specialists in Turkic philology prefer to write in Russian or in English, in order to communicate with colleagues worldwide. Another factor in favor of Russian in academic life is a long scientific tradition, whereas there is almost no tradition of participating in the English-dominated scholarship and a lack of English-language competence among academics. In a study of communication and access to information in science, Djenchuraev (2004) found that scientific institutions are worse financed and maintained than during the Soviet times, scientific production is commonly based on paper technologies; scholars, including members of the younger generation, cannot use English, and $22-24 \%$ are not properly acquainted with computers and the Internet; as a result, access to local or worldwide scientific literature is difficult. What is proposed is the development of a national scientific and technical information system and virtual laboratories.

Despite the predominance of Russian in academic life, ethnic diversity of the speakers of Russian and the influences of their mother tongues upon the Russian they speak work as pidginization factors, a situation that concerns local linguists. Recently, several international conferences dedicated to the linguistic situation in Kyrgyzstan and the future of the Russian language were held in Kyrgyzstan. The Congress on the problems of the Russian language in the CIS-countries (Bishkek, 4-6 March, 2004) was dedicated to the strengthening of the position of the Russian language in Central Asia and the strengthening of the relations with Russia (Orusbaev et al., 2005). A Forum on the functioning of the Russian language in the Central Asian region of the member states of the CIS (Bishkek, 7-9 December, 2006) was sponsored through the Russian non-commercial educational-training expert foundation within the framework of the Federal program 'Russian language'. This forum emphasized the need to review the teaching of the Russian language and its use in the mass media with the goal of enhancing its role in the cultural, humanitarian, and educational spheres of collaboration (Arzygulova, 2007; Marchenko, 2007).

\section{Current Education Policies and Practices}

The distribution of languages in Kyrgyz education begins with preschool institutions. According to the Ministry of Education of Kyrgyzstan, in the year 2005-2006, 448 preschool institutions operated in Kyrgyzstan, and 50,365 children were attending these institutions. Of these, 120 operated in Kyrgyz, 235 in Russian, 76 used both languages of instruction, and 17 preschools, run by a Swiss organization CIMERA, were multilingual. In the capital Bishkek, the number of children attending day-care centers was 517,561 . There were 73 
preschool institutions in Bishkek, out of which 63 served all children and 10 children with special needs. Out of the 63 mainstream preschools, 40 were Russian-medium, 6 Kyrgyz-medium, 6 Kyrgyz-Russian bilingual, and 11 multilingual.

In terms of secondary schools, in the school year 2005-2006, according to the Ministry of Education, there were 2,091 ${ }^{1}$ public schools in Kyrgyzstan (359 in towns and 1,732 in the countryside). Of these, 20 schools were designated for children with special needs. Table 2 reflects the distribution of languages in the remaining 2,071 schools.

Children of Russian parents mainly study in Russian-medium schools, and many non-Russian parents send their children to Russian-medium schools as well, even at the expense of potential fluency in the native language. In all of the minority schools that teach in Uzbek, Tajik, Turkish, German, and other languages, the Kyrgyz and Russian languages are taught as compulsory subjects. According to the Ministry of Education curriculum standards, the hours dedicated to the Kyrgyz language and literature are distributed as follows:

- in Russian-medium schools the Kyrgyz language is taught in the 1st grade for 3 hours/week - 100 hours/year; in the 2nd-4th grades, 4 hours/week or 140 hours/year, in the 5th-7th grades, 3 hours/week or 100 hours/year, in the 8th-11th grades, 2 hours/week or 70 hours/year. Kyrgyz literature is taught in the 5th-11th grades for 1 hour/week, or 35 hours/year.

- in Uzbek and Tajik schools the Kyrgyz language is taught in the 1st-11th grades for 2 hours/week, or 70 hours/year, and Kyrgyz literature is taught in the 5th-11th grades for 1 hour/week, or 35 hours/year.

As seen in Table 2, 509 schools offer Russian-medium instruction, 148 of these are fully Russian-medium and 361 are mixed. Due to the diminished status of the Russian language, levels of Russian-language knowledge have also decreased, and there are increasing numbers of students without preexisting Russian language skills in Russian-medium schools. Among firstgraders in general only about $5 \%$ can speak Russian. The demand for Russian language teachers is high, and not all vacancies are filled. Due to general poverty, schools are facing a shortage of appropriate textbooks and other materials, and insufficient in-service training for educators (Chepurnyh, 2005: 128-131). The new generation of Russian textbooks is created in reciprocal collaboration with colleagues from Moscow, where the Kyrgyz language is taught at the Linguistic University.

Overall, the educational system varies by region and nowadays it may be considered old-fashioned, incomplete, and deficient in methods and materials. Teachers have low salaries, schools lack instructional materials, and educational structures are permeated with corruption. The choice of language for teaching is often situation-oriented and depends on the mother tongue of the teacher and students. Teachers may also lack competence in the language(s) of instruction. It can happen that a teacher, especially in the countryside, does not have good command of the Russian language in which s/he teaches (or vice 
Table 2 Distribution of secondary schools according to language(s) of instruction

\begin{tabular}{|l|r|r|r|r|r|r|r|r|r|r||}
\hline & & Osh region & Jalal-Abad & Batken & Talas & Chui & Issyk-Kul & Naryn & Osh-city & Bishkek City \\
\hline All schools & 2,071 & 511 & 450 & 220 & 114 & 306 & 193 & 141 & 54 & 82 \\
\hline Single-language instruction & 1,634 & 461 & 364 & 191 & 94 & 195 & 134 & 131 & 31 & 33 \\
\hline Kyrgyz & 1,360 & 395 & 321 & 164 & 90 & 121 & 126 & 126 & 13 & 4 \\
\hline Russian & 142 & 5 & 8 & 3 & 4 & 74 & 8 & 5 & 6 & 29 \\
\hline Uzbek & 129 & 61 & 35 & 21 & & & & & 12 & \\
\hline Tajik & 3 & & & 3 & & & & & & \\
\hline Instruction in 2 or 3 languages & 437 & 50 & 86 & 29 & 20 & 111 & 59 & 10 & 23 & 49 \\
\hline Kyrg-Rus & 322 & 13 & 44 & 9 & 20 & 110 & 59 & 10 & 8 & 49 \\
\hline Kyrg-Uzb & 54 & 19 & 23 & 11 & & & & & 1 & \\
\hline Kyrg-Taj & 2 & 1 & & 1 & & & & & & \\
\hline Uzb-Rus & 40 & 14 & 11 & 3 & & 1 & & & 11 & \\
\hline Uzb-Taj & 2 & & & 2 & & & & & & \\
\hline Kyrg-Uzb-Rus & 16 & 3 & 8 & 2 & & & & & 3 & \\
\hline Uzb-Taj-Rus & 1 & & & 1 & & & & & & \\
\hline
\end{tabular}


versa in the big cities). It may occur that a teacher at a Kyrgyz school teaches mathematics in Russian. Overall, language teaching is old-fashioned and lacks motivational stimuli (Korth, 2005). Not all of the regular schools have teachers of foreign languages. According to the Ministry of Education, in the school year 2005-2006, 1,909 of the 2,071 schools offered foreign language instruction: English was taught at 1,769 schools to 947,928 students, French was taught at 44 schools to 8,128 students, and German was taught at 266 schools to 64,933 students.

A Swiss organization CIMERA (www.cimera.org), operating through four non-governmental organizations, Interethnic Integration for Promoting Multilingualism in Bishkek (IMEMB), Multilingual Education in Southern Kyrgyzstan (MOJUK), Multilingual Education in the Naryn Region (MONR) and Multilingual Education in the Chui Region (MOChR), later merged into the association 'Til-Dil', is promoting multilingual education. From the year 2000 on, 14 schools and 17 preschools located in Chui, Naryn, Jalal-Abad, Batken and Osh provinces offered such multilingual instruction.

In higher education, there are more than 50 universities in Kyrgyzstan, including more than 30 in Bishkek alone. Among these universities are the Kyrgyz National University, Bishkek Humanities University, International University of Kyrgyzstan, International Ataturk-Alatoo University, KyrgyzTurkish MANAS University, the American University of Central Asia, the Kyrgyz-Russian Slavic University, the Kyrgyz-Russian Academy of Education, and five branches of Russian institutions of higher education. In the South, there are the State University of Osh, State University of Jalal-Abad, State University of Batken, the Kyrgyz-Uzbek University in Osh, the Osh Technological University, the private Uzbek Batyrov Jalal-Abad University, the Kyrgyz-Russian Pedagogical Institute of the Humanities in Osh, and the University of Peoples' Friendship in Jalal-Abad. In the North, besides Bishkek, there are influential State Universities in Issyk-Kul and Naryn. As seen in the sponsorship, some of these universities represent different forces fighting for influence in the republic: Turkey, the USA, the EU, Russia, Uzbekistan, and Tajikistan. The image of Turkey, according to our informants from different layers of society, is considered by most of the population as a desirable model for managing national progress. Turkish study is supported through regular grants for Kyrgyz students to study in Turkey (several thousand young Kyrgyz attend institutions of higher education there). The International Education Institute SEBAT and several lyceums and colleges are offering Turkish studies in Kyrgyzstan itself.

Instruction in higher education is offered in several languages, oftentimes within the same university, e.g. in the Kyrgyz-Turkish MANAS University instruction is offered in Turkish, English, and Kyrgyz. Overall, in the humanities, the main languages are Kyrgyz and Russian, some instruction is also offered in Uzbek, English and Arabic. In socioeconomics, Russian is used everywhere, one may also encounter some Kyrgyz, Uzbek and English. In natural sciences and technology, Russian also dominates, and Kyrgyz and Uzbek are employed at some universities. The distribution varies geographically. At the universities in the South, first-year and, partly, second-year 
students study in their mother tongue, Kyrgyz or Uzbek, and then switch to Russian. In the North, disciplines of general value are predominantly taught in Russian. Faculties and departments of Kyrgyz philology operate in Kyrgyz, while computer science, communication, and military science are taught in Russian. English is used at the American University of Central Asia, as well as in various firms, companies, non-governmental organizations and foundations. Arabic is gaining a foothold through the Islam University of Kyrgyzstan, the Kyrgyz-Kuwait University and many other religious educational institutions. In addition to Arabic and Turkish, young people enjoy the opportunity to frequent cultural centers of the foreign countries, and to attend courses in English, French, German, Italian, Chinese, Korean, and Japanese. Ever since Russian has lost its position as the main language of instruction, the battle for influence is fought on the linguistic field as well.

Nevertheless, young Kyrgyz still have good reasons to be fluent in Russian. To be well educated means to be acquainted with Russian literature and to speak Russian, with Moscow universities ranking high among the young people, and employment in Russia being considered great opportunity (Marat, 2006b). Hundreds of Kyrgyz youngsters receive free university education in Russia every year. Some 900,000 ethnic Kyrgyz are currently working in Russia, and most of these are of the reproductive age. These Kyrgyz send about \$300-500 million in remittances back home every year, an amount comparable to the annual budget of Kyrgyzstan (Tiazhlov, 2006). The program 'Russian language in Kyrgyzstan', to be implemented in 2006-2010, is aimed to prepare new emigrants to work and live in Russia (Rudov, 2007b). Immigrants from Pakistan, India, China, and Turkey who come to Kyrgyzstan also commonly study Russian in order to be able to move to Russia where they may have better employment opportunities.

To support the teaching of Russian, the Ministry of Education, Science and Youth Policy of the Kyrgyz Republic publishes the journal Russkij iazyk $i$ literatura $v$ shkolah Kyrgyzstana (Russian language and literature in Kyrgyzstan schools). This journal offers teachers of Russian an opportunity to discuss their research, personal experiences, interesting linguistic facts, methods of language teaching, information about professional education, conferences and books. The new tendency in Kyrgyzstan is to introduce the following elements into the teaching of Russian: (a) ethnocultural elements of traditional Russian life as foreign to Kyrgyz people; (b) discussion of the history and present day of the Russian-speaking community in Kyrgyzstan; (c) reflections on the Kyrgyz way of life in Russian language and culture. The Russian ethnoculture is taught through word-formation, poetic styles, and key characters of the Russian literature.

Russian-speakers are also offered opportunities to learn Kyrgyz. There are courses for adult learners of Kyrgyz. There are also several types of textbooks, phrase-books and manuals of Kyrgyz for adults, manuals of spoken Kyrgyz for Russian language teachers, and texts for agronomists and other specialists (e.g. Isaev \& Shneidman, 1988; Kasymova, Toktonaliev, \& Karybaev, 1991). Even old manuals are updated, as the one proposed in 1935 by Polivanov (Batmanov \& Aktanov, 2007). Some manuals are created specifically for 
secondary school and higher education students (e.g. Turgambaeva \& Usekova, 2004; Zhusaev et al., 2001).

\section{Preliminary INTAS Survey Results}

The international INTAS project 'New language identity in transforming societies: Kazakhstan, Kyrgyzstan, Tajikistan and Uzbekistan' (INTAS Ref. N 04-79-7292) was carried out in 2005-2007 by six national teams (four from the countries studied in the project and two from Israel and Finland serving as coordinators) (see also Smagulova, this issue). The study had three main goals. The first was to examine the relationship between ethnic distinctiveness and the emerging state or national identity and to redefine the links between national, ethnic and linguistic belonging in Kyrgyzstan as a Central Asian state and society in transition. The second goal was to find out what kind of individual and social circumstances and attitudes affect language identity change, if such a change takes place, at ethnic, national, and individual levels. The third goal was to articulate the relations between titular, Russian, and other ethnic groups. Ethnicization in the countries is growing, and the attitudes towards languages and language policies are reflected in the language preferences.

The level of ethnic language distinctiveness of minority groups in Central Asia was evaluated on the basis of questionnaires distributed among 1,000 Kyrgyz, 1,000 Russians, and 1,000 representatives of other ethnic minorities in a nationwide design, in different regions of the country, aiming at people from different socioeconomic backgrounds and at two age groups: (1) 16-17 year old students in their last year of high-school; they grew up in independent Kyrgyzstan and represent the new generation relatively free of the past Soviet ideology; responses from this group could provide insights into the future of the national, ethnic, and individual identity; (2) 55-65 year old retirees whose ideology and everyday practices were formed under the Soviet regime, and who are gradually losing their societal influence; these people still play an important role in the country, especially because elder people are highly respected, yet they had to adjust to both political changes and technical progress.

The questions were subdivided into the following: (1) examination of the respondents' beliefs on whether nationalization, assimilation, cultural diversity, or bilingualism would better describe their sociolinguistic reality, past and present; (2) individuals' perception of and attitudes towards the changing ethnic composition of the new nations, including the size of different groups, levels of migration, and prognosis for the future; (3) consideration of language choices and in/out-group ethnic versus interethnic contacts in various compositions and constellations, the contexts including family and friendship circles, school, and the workplace; (4) language proficiency in national/state and native/minority languages as self-assessed at present and in retrospective (to be compared to existing findings from the previous years).

The respondents were asked about their intentions in the matter of language behavior, actual language use, experience with other languages 
and attitudes towards the role of different languages. Special focus was on Russians who have lost their previous heavyweight status and must adjust to new realities of the transforming societies, on the self-identification of different groups, and on intermarriages and children's linguistic upbringing (Suleimenova et al., 2005).

The questionnaires were distributed in six languages (four state languages, Russian and English), while representatives of the 'small' minorities agreed to fill them out in Russian. The study showed that the ethnic composition of Kyrgyzstan varies between the towns and villages. It is also reflected in multilingual constellations: the urban population prefers to converse in Russian in cities with a significant proportion of administrative and highly educated workforce and in Kyrgyz in cities with numerous factories and plants. In the countryside, Kyrgyz is often in use together with Uzbek or Tajik languages, and some villages are even trilingual. The Kyrgyz prefer in-group marriages; Russians mostly constitute part of multinational communities and are more exogamic.

The results of preliminary data analysis show a certain dynamic towards stabilization of the linguistic status quo. ${ }^{2}$ Some $52 \%$ of the Kyrgyz reported that they prefer to bring their children up as Kyrgyz monolinguals, $46 \%$ favored bilingualism, and others had no opinion. Among the speakers of Russian, about $44 \%$ opted for monolingualism in Russian, $45 \%$ for multilingualism in different languages, and $11 \%$ had no opinion. Among other nationalities, $48 \%$ inclined towards one-language-use, $42 \%$ wanted more languages at home, and $10 \%$ were not sure. To know one's own language is considered crucial by $85 \%$ of the Kyrgyz, $88 \%$ of Russians, and $82 \%$ of other minority language speakers. With regard to the definition of nationality, living on the same territory was less important for all of the groups, but the connection to the mother tongue was emphasized above all other factors by $70 \%$ of the Kyrgyz, $61 \%$ of Russians, and by most of the minority respondents. National consciousness and identification came in the second place, and religion occupied the third position among all respondents. Formulating their attitudes towards people of the same nationality not knowing their ethnic language, $46 \%$ of the Kyrgyz, $36 \%$ of Russians, and $41 \%$ of other ethnic minorities were tolerant; 19,36 , and $32 \%$, respectively, were rather negative; and 30,12 , and $8 \%$, respectively, distinctly negative; the remainder had no opinion.

The concept of ethnicity (natsionalnost') was considered important, whereas the concept of citizenship was often seen as not deep enough. Should those who speak Russian be Russian? Should Koreans living in Kyrgyzstan who do not speak Korean be proclaimed Koreans, Russians or Kyrgyz? Reflecting on the possibility of ascribing particular ethnicity to those who do not speak their 'own' language, $44 \%$ of the Kyrgyz were positive and 33\% negative; among Russians, $36 \%$ were positive and $12 \%$ negative; among representatives of other ethnic groups, $32 \%$ were positive and $8 \%$ negative. Self-acceptance as a representative of one's own ethnicity was high: 93\% among the Kyrgyz, 88\% among Russians, and $67 \%$ among other minorities. $87 \%$ of the Kyrgyz, $80 \%$ of Russians, and $67 \%$ of other minorities were ready to protect their mother tongues. When asked whether Russian can be the mother tongue for 
representatives of other ethnicities, 34\% of the Kyrgyz, 79\% of Russians, and $71 \%$ of members of other ethnic minorities replied positively; $50 \%$ of the Kyrgyz, $11 \%$ of Russians, and $17 \%$ of others rejected such possibility. Only $43 \%$ of the Kyrgyz, $22 \%$ of Russians, and $22 \%$ of other minorities felt secure about the future of their native tongues in Kyrgyzstan; the proportion of those who were very worried was $6 \%$ of the Kyrgyz, $15 \%$ of Russians, and $26 \%$ of other minorities. When representatives of other ethnicities speak the language of the respondent's ethnicity, $86 \%$ of the Kyrgyz, $95 \%$ of Russians, and $86 \%$ of other minorities positively accept them. Some $42 \%$ of the Kyrgyz do not want Russians to leave the country (16\% take the contrary view) and $66 \%$ of the Kyrgyz are worried about the fact that ethnic Kyrgyz are leaving the country. In terms of age differences, the younger generation appears to take a positive attitude towards multiple identities, multilingualism, and cosmopolitanism, whereas the older generations have come to accept the status quo.

These results demonstrate that to be Kyrgyz and to speak Kyrgyz is becoming increasingly important for Kyrgyz people; Russian remains useful, but most Russians want their children to speak many languages. Those who have already lost their mother tongue, or have not learned it at all, are more skeptical about the future of the Kyrgyz language as covering all needs of Kyrgyzstani people. Still, the survey lacks the real histories of the people: some had no opportunity to experience balanced successful bilingualism and think that it is not possible.

\section{Conclusions}

The Kyrgyz survey has demonstrated that the issues of language, ethnicity, and identity affect the ethnic revival while mobilizations of ethnicity and nationalism involved a renewed emphasis on language. Operating mostly inside the borders inherited from the Soviet era, the New Independent States were forced to redefine themselves in many aspects. Until now, regular life could not be organized without at least some recourse to Russian. Local intelligentsia leaned upon the established values, the ideals of the great literature and Russian democratic tendencies of the late nineteenth and twentieth centuries, but with time they became more and more isolated from developments in Russian culture and the sciences. This adherence to tradition is seen in the fact that Kyrgyz scholars, writers and artists are still aspiring to a better future, equality for all, and accessibility of good education for the talented youth, while Russian intelligentsia in Russia focuses on achieving financial success and elite status. Russian administration is increasingly investing in the study of Russian outside Russia, study in Russia, and migration to Russia. As a result, the Kyrgyz-Russian Slavic University can pay better salaries to its personnel than its rivals, offer more modern textbooks and technical facilities, and employ the best teachers.

To sum up, it appears that those who remain in Kyrgyzstan will face Kyrgyzification of most of the country, Uzbekization of the South, KyrgyzRussian bilingualism in the cities, and Kyrgyz-Russian-English-Turkish multilingualism of the elite. Russian remains important as a means of official, interethnic and worldwide communication, and the government is discussing 
measures for the maintenance of high-quality Russian in the mass media and other public uses (i.e. keeping up with the standard norms, avoiding corroded or low-status varieties, etc.). In order to reach these goals, the Kyrgyz Republic needs, among other things, high-quality Russian language teaching, good libraries and textbooks, comparative linguistic research and linguistic descriptions of real language use, and access to massive scientific and cultural sources in Russian. At the same time, the new Russian influence is in competition with western and Islamic influences, although so far Western scholars have not been as influential inside Kyrgyzstan as they aspired to be. In addition, despite great interest in foreign languages, especially English, Turkish and Arabic, only a small percent of those who would like to study them properly has access to up-to-date facilities and resources. The need to understand languages of the neighboring countries also suggests that Chinese should be added to the array of foreign languages taught in Kyrgyzstan (Orusbaev, 2003a).

\section{Correspondence}

Any correspondence should be directed to Abdykadyr Orusbaev, KyrgyzRussian Slavic University (orusbaev@mail.ru) or to Ekaterina Protassova, University of Helsinki (ekaterina.protassova@helsinki.fi)

\section{Notes}

1. The number of schools continues to grow, and in the year 2007-2008 more than a hundred new schools were opened in Kyrgyzstan (Erkintoo, 23 November, 2007).

2. More precise data will be provided in later publications, the final published data may be slightly different from the numbers reported here.

\section{References}

Abduldaev, Е. [Абдулдаев, Э.] (1998) Азыркы кыргыз тили: Фонетика,Орфоэпия. Графика жана орфография. Лексикология жана фразеология. [Krygyz Language: Phonetics, Orthoepics, Orthography, Lexicology, and Phraseology]. Bishkek: Kyrgyzstan.

Abdymambetova, Е. [Абдымамбетова, Э.] (2001) Кыргыз Тили [The Kyrgyz Language]. Bishkek: Kyrgyzsko-rossijskij Slavianskij universitet.

Andreeva, I. and Khruslov, G. [Андреева, И. \& Г. Хруслов] (2004)Функиионирование русского языка в странах СНГ и Балтии [Functioning of the Russian Language in the CIS and Baltic Countries]. Moscow: Ministry of Education of the Russian Federation.

Arzygulova, S. [Арзыгулова, C.] (2007) Становление и развитие русско-туземных школ в Кыргызстане [Formation and development of Russian-aboriginal schools in Kyrgyzstan]. In Russkij iazyk, 2007a, pp. 259-262.

Ashirbaev, T. and Ahmatov, Т. [Аширбаев Т. \& Т. Ахматов] (2001) Деловые бумаги: Делопроизводство на государственном языке [Official Papers: Writing Documents in the State Language]. Bishkek: Center of the State Language and Encyclopaedia.

Batmanov, I. and Aktanov, Т. [Батманов, И. \& Т. Актанов] (2007) Кыргыз тилинин окуу китеби: Башталгыч курс [Textbook of Kyrgyz Language. A Beginner's Course]. Bishkek: ARXI.

Berdikeeva, S. (2006) National identity in Kyrgyzstan: The case of clan politics. Paper presented at 11th Annual World Convention 'Nationalism in an Age of Globalization', Columbia University, New York, 23-25 March. On WWW at www.Eurasia21.com. Accessed 1.2.07. 
Bergne, P. (2003) The politics of language in the ex-Soviet Muslim states. Journal of Islamic Studies 14, 245-247.

Bingol, Y. (2004) Nationalism and democracy in post-communist Central Asia. Asian Ethnicity 5 1, 43-60.

Brubaker, R. (1994) Nationhood and the nationalities question in the Soviet Union and Post-Soviet Eurasia. Theory and Society 23 (1), 47-78.

Chepurnyh, Е. [Чепурных, Е.] (еd.) (2005) Русский язык в мире: современное состояние и тенденции распространения [Russian Language in the World: Actual State of Things and the Tendencies of Spread], Issue 3. Moscow: The Ministry of Foreign Affairs of the Russian Federation.

Commercio, M. (2004) Exit in the near abroad: The Russian minorities in Latvia and Kyrgyzstan. Problems of Post-Communism 51 (6), 23-32.

Derbisheva, Z. [Дербишева, 3.] (2007) Региональный “портрет” русского языка в Кыргызстане [A regional 'portrait' of the Russian language in Kyrgyzstan]. In Russkij iazyk, 2007b, pp. 20-25.

Djenchuraev, N. (2004) Toward a new policy for scientific and technical communication: The case of the Kyrgyz Republic. CoRR: Computers and Society. On WWW at xxx.arxiv.org/ftp/cs/papers/0405/0405001.pdf. Accessed 1.2.07.

Duishekeeva, A. [Дуйшекеева, A.] (2007) Русскоязычное радиовещание Кыргызстана [Russian language broadcasting in Kyrgyzstan]. In Russkij iazyk, 2007b, pp. 69-73.

Dukenbaev, A. and Hansen, W. (2003) Understanding politics in Kyrgyzstan. In O. Nørgaard and L. Johannsen (eds) DEMSTAR Research Report No. 16. Department of Political Science, University of Aarhus; Department of International and Comparative Politics, American University - Central Asia. On WWW at www.demstar. dk. Accessed 1.2.07.

Elebayeva, A., Omuraliev, N. and Abazov, R. (2000) The shifting identities and loyalties in Kyrgyzstan: The evidence from the field. Nationalities Papers 28 (2), 343-349.

Fagerlind, I. and Kanaev, A. (2000) Redefining citizenship education in the Central Asian countries. Educational Practice and Theory 22 (1), 95-113.

Fedchina, V.N. [Федчина B.Н.] (1967) Как создавалась карта Средней Азии [How the Map of Central Asia was Created]. Moscow: Nauka.

Fierman, W. (1997) Language, identity, and conflict in Central Asia and the Southern Caucasus. Perspectives on Central Asia 2 (5), 1-4.

Giger, M. and Sloboda, M. (2008) Language management and language problems in Belarus: Education and beyond. International Journal of Bilingual Education and Bilingualism, this issue.

Gleason, G. (2001) Foreign policy and domestic reform in Central Asia. Central Asian Survey 20 (2), 167-182.

Glumskov, D. [Глумсков, Д.] (2006) Перерыв на митинг [Pause for a gathering]. Эксnерт, Обзоры стран [Expert, Reviews of the countries] 9, 14. On WWW at www.expert.ru/printissues/countries/2006/09/kirgiziya/. Accessed 1.2.07.

Grigorieva, O. and Parmanasova, S. [Григорьева, O. \& \& C. Парманасова] (2007) Русский язык в государственных учреждениях города Бишкека (по результата социолингвистического обследования) [Russian language in the state institutions of the city of Bishkek (based on the results of a sociolinguistic inquiry]. In Russkij iazyk, 2007b, pp. 56-59.

Heuer, B. (2001) Til tagdary - ël tagdyry': Das Schicksal der Sprache ist das Schicksal des Volkes - ein Jahrzehnt Sprachenpolitik im unabhängigen Kyrgyzstan [Language destiny is people's destiny: A language policy decade in the independent Kyrgyzstan]. Berliner Osteuropa Info, [Berlin's Info about Eastern Europe] 17, 24-30.

Hirsch, F. (2005) Empire of Nations: Ethnographic Knowledge and the Making of the Soviet Union. Ithaca, NY: Cornell University Press.

Huskey, E. (1995) The politics of language in Kyrgyzstan. Nationalities Papers 23 (3), 549-572. 
Isaev, D. and Shneidman, V. [ИсаеввД. \& Шнейдман, в.] (1988) Краткий самоучитель киргизского языка [Short Textbook of the Kyrgyz Language]. Frunze: Mektep.

Kasymova, B., Toktonaliev, K. and Karybaev, А. [Касымова Б, Токтоналиев К. \& А. Карыбаев] (1991) Изучаем киргизский язык [We are Studying Kyrgyz]. Frunze: Mektep.

Khazanov, A.M. (1995) After the USSR: Ethnicity, Nationalism, and Politics in the Commonwealth of Independent States. Madison: University of Wisconsin Press.

Khruslov, G. [Хруслов, Г.] (2006) Функционирование русского языка в странах СНГ [Functioning of the Russian language in the CIS-countries]. Russian Language Journal 56 (5), 131-166.

King, C. and Melvin, N. (1999-2000) Diaspora politics: Ethnic linkages, foreign policy, and security in Eurasia. International Security 24 (3), 108-138.

Kirgizskaja SSR (1982) Киргизская ССР: Энщиклопедия [Kyrgyz SSR: Encyclopedia]. Frunze: Glavnaja redakcija Kirgizskoj Sovetskoj Enciklopedii.

Koenig, M. (2000) Social conditions for the implementation of linguistic human rights through multicultural policies: The case of the Kyrgyz Republic. In S. Wright (ed.) Language Policy and Language Issues in the Successor States of the Former USSR (pp. 57-83). Clevedon: Multilingual Matters.

Kolpakov, A. (2001) Managing Diversity in Kyrgyzstan. Bloomington, IN: School of Public and Environmental Affairs, Indiana University.

Kolstoe, P. (1995) Russians in the Former Soviet Republics. Bloomington, IN: Indiana University Press.

Korth, B. (2005) Language Attitudes Towards Kyrgyz and Russian: Discourse, Education and Policy in Post-Soviet Kyrgyzstan. Bern: Peter Lang.

Kosmarskaya, N. [Космарская,Н.] (2006) «Дети империи» в постсоветской Центральной Азии: адаптивные практики и ментальные сдвиги (русские в Киргизии, 1992-2002) ['Children of the Empire' in Post-Soviet Central Asia: Mental Shifts and Practices of Adaptation (Russians in Kirghizia, 1992-2002)]. Moscow: Natalis.

Krasnov, F. [Краснов, Ф.] (ed.) (1998) Русский язык в Кыргызстане [Russian Language in Kyrgyzstan]. Issue I. Bishkek: Kyrgyzsko-rossijskij Slavianskij universitet.

Krasnov, F. [Краснов, Ф.] (еd.) (2000) Русский язык в Кыргызстане [Russian Language in Kyrgyzstan]. Issue II. Bishkek: Kyrgyzsko-rossijskij Slavianskij universitet.

Krasnov, F. [Краснов, Ф.] (еd.) (2002) Русский язык в Кыргызстане [Russian Language in Kyrgyzstan]. Issue III. Bishkek: Kyrgyzsko-rossijskij Slavianskij universitet.

Kreindler, I. (1997) Multilingualism in the successor states of the Soviet Union. Annual Review of Applied Linguistics 17, 91-112.

Kuchukeeva, A. and O'Loughlin, J. (2003) Civic engagement and democratic consolidation in Kyrgyzstan. Eurasian Geography and Economics 44 (8), 557-587.

Laitin, D. (1996) Language and nationalism in the post-Soviet Republics. Post-Soviet Affairs 12 (1), 4-24.

Landau, J. and Kellner-Heinkele, B. (2001) Politics of Language in the ex-Soviet muslim States: Azerbaijan, Uzbekistan, Kazakhstan, Kyrgyzstan, Turkmenistan, Tajikistan. London: C. Hurst.

Law of the Kirgiz Soviet Socialist Republic on the state language of the Kirgiz republic [Закон Киргизской Советской Социалистической Республики о государственном языке Киргизской Республики] (1989) Frunze: Kyrgyzstan.

Law on the Official Language of the Kyrgyz Republic [Закон Кыргызской Республики об официальном языке Кыргызской Республики] (2000) Bishkek: Uchkun.

Law on the State Language of the Kyrgyz Republic [Закон о государственном языке Кыргызской [О плане мероприятий] (2004) Bishkek: Bajtik. 
Maksimenko, O. [Максименко, О.] (1999). Функциональное распределение языков на предприятиях города Бишкека [Functional Distribution of Languages in the Bishkek institutions]. An unpublished Master's Thesis. Bishkek: Kyrgyzskorossijskij Slavianskij universitet.

Mamedov, N. (2005). Ethnocultural Practices in Post-Soviet Kyrgyzstan and Turkmenistan: A Comparative perspective. An unpublished Master's Thesis. Budapest: Central European University.

Marat, E. (2006a) The Tulip Revolution: Kyrgyzstan One Year After. Washington, DC: The Jamestown Foundation.

Marat, E. (2006b) Russian mass media shape public opinion in Kyrgyzstan. Eurasia Daily Monitor 3, 226. On WWW at www.eurasiadaily.org. Accessed 1.2.07.

Marchenko, L. [Марченко, Л.] (2007) Политика адмнинистрации Туркестанского края в области образования во второй половине XIX - начале XX века [Turkestan region educational policy in the second half of the 19th and the beginning of the 20th century]. In Russkij iazyk, 2007a, pp. 280-283.

Mullerson, R. (1993) Minorities in Eastern Europe and the former USSR: Problems, tendencies and protection. The Modern Law Review 56 (6), 793-811.

Olcott, M.B. (1997) Democratization and the growth of political participation. In K. Dawisha and B. Parrot (eds) Conflict, Cleavage, and Change in Central Asia and the Caucasus (pp. 201-241). Cambridge: Cambridge University Press.

Orusbaev, A. [Орусбаев, А.] (2003а) Русский язык как этнокоммуникативный компонент дву- $и$ многоязычия в Кыргызстане [Russian Language as an Ethnocommunicative Component of Bi- and Multilingualism in Kyrgyzstan]. Bishkek: Ministry of Education and Culture of the Kyrgyz Republic.

Orusbaev, A. [Орусбаев, A.] (ed.) (2003b) Русский язык Кыргызстане [Rиssian Language in Kyrgyzstan]. Proceedings of the International Conference. Bishkek: Kyrgyzsko-rossijskij Slavjanskij universitet.

Orusbaev, A. [Орусбаев, A.] (2003c) Русский язык в независимой Киргизии [Russian language in the independent Kirgizia]. Diaspory 1, 146-160.

Orusbaev, A., Rudov, M. and Shepeleva, G. [Орусбаев, А., Рудов М. \& Г. Шепелева] (2005) Русский язык в сообществе народов СНГ [The Russian Language in the Community of the CIS-peoples]. Bishkek: The Kyrgyz-Russian Slavic University.

Oruzbaeva, В. [Орузбаева, Б.] (1997) Очерк о киргизском языке [Essay on the Kyrgyz language] In Языки мира, 2-й том: Тюркские языки [World Languages (2nd Vol.) Turkic Languages] (pp. 286-298). Bishkek: Kyrgyzstan.

Pannier, B. (1996) Linguistic dilemma in Kyrgyzstan. Transition 29, 28-29.

Pavlenko, A. and Blackledge, A. (2004) Introduction: New theoretical approaches to the study of negotiation of identities in multilingual contexts. In A. Pavlenko and A. Blackledge (eds) Negotiation of Identities in Multilingual Contexts (pp. 1-33). Clevedon: Multilingual Matters.

Rotar, I. [Ротар, И.] (2006) Исламские войны [Islamic wars]. Moskovskie novosti, 35 (September 15, 2006).

Rudov, M. [Рудов, M.] (2007а) Роль русского языка в адаптации трудовых мигрантов из Кыргызстана [The role of the Russian language in the adaptation of labor migrants from Kyrgyzstan]. In Языковая политика в современном мире [Language Policy in the Modern World] (pp. 225-226). St Petersburg: Zlatoust.

Rudov, M. [Рудов, M.] (2007b) Новые стимулы и ресурсы распространения русского языка в Центральноазиатском регионе [New stimuli and resources for the spread of the Russian language in the Central Asia region]. In Russkij iazyk, 2007b, pp. 34-37.

Russkij iazyk (2007a) Русский языкв образовательном пространстве Центральноазиатскогорегиона СНГ. Международная научно-практическая конференция [Russian Language in the Educational Sphere of the Central Asia Region of the CIS. Scientific-practical Conference]. Bishkek: The Kyrgyz-Russian Slavic University.

Russkij iazyk (2007b) Русский языкв иеентральноазиатском регионе государств-участников СНГ. Международный форум. [Russian Language in 
the Central Asia Region of the CIS. An International Forum]. Bishkek: The KyrgyzRussian Slavic University.

Sartbaev, К. [Сартбаев, К.] (1986) Языковедение в Киргизии [Linguistics in Kirgizia]. Frunze: Ilim.

Savoskul, S. [Савоскул, С.] (2001) Русские нового зарубежья: Выбор судьбы [Russians of the New Abroad: The Choice of Destiny]. Moscow: Nauka.

Schlyter, B. (2001) Language policies in present-day Central Asia. International Journal on Multicultural Societies 3 (2), 127-136.

Schulter, B. (2003) Language and identity: the situation in Kyrgyzstan and the role of pedagogy. CIMERA Conference Proceedings 5, 20-27.

Shipilov, A. [Шипилов, A.] (2007) Русский язык в геополитике Киргизской Республики [Russian language in the geopolitics of the Kyrgyz Republic]. Русский язык за рубежсм [Russian language abroad] 1, 108-115.

Smagulova, J. (2008) Language policies of kazakhization and their influence on language attitudes and use. International Journal of Bilingual Education and Bilingualism, this issue.

Smith, G., Law, V., Wilson, A., Bohr, A. and Allworth, E. (1998) Nation-building in the Post-Soviet Borderlands: The Politics of National Identities. Cambridge: Cambridge University Press.

Suleimenova, E., Shaimerdenova, N. and Smagulova, J. (2005) New Language Identity in Transforming Societies: Kazakhstan, Kyrgyzstan, Tajikistan and Uzbekistan. Methodology of Research. Almaty: Kazakh University.

Tagaev, M. [Тагаев, M.] (2004) Русский язык в коммуникативном пространстве юга Киргизии. Опыт социолингвистического и лингводидактического анализа [Russian language in the communicative dimension of the Kyrgyz south. A sociolinguistic and language-education perspective]. Статистический ежегодник [Russian Language Abroad] 2, 108-111.

Tishkov, V. (1997) Ethnicity, Nationalism and Conflict In and After the Soviet Union: The Mind Aflame. London: UNRISD/Sage Publications.

Tiazhlov, I. [Тяжлов, И.] (2006) Великое непереселение [The great non-migration]. Kommersant, 168, 1, September 11, 2006.

Turgambaeva, A. and Usekova, А. [Тургамбаева, А. \& А. Усекова] (2004) Кыргыз тили [Kyrgyz Language]. Bishkek: Uchkun.

Wright, S. (1999) Kyrgyzstan: The political and linguistic context. Current Issues in Language \& Society 6 (1), 85-91.

Zhusaev, Zh., Kanybekova, A. and Karabekov, А. [Жусаев, Ж.,, Каныбекова, А. \& А. Карабеков] (2001) Кыргызз тили [Kyrgyz Language]. Bishkek: Mektep. 